\title{
Impact of Prosopis (mesquite) invasion and clearing on vegetation species composition and diversity in semi-arid Nama-Karoo rangeland, South Africa
}

\author{
Thabisisani Ndhlovu, Suzanne J Milton \& Karen J Esler
}

To cite this article: Thabisisani Ndhlovu, Suzanne J Milton \& Karen J Esler (2016) Impact of Prosopis (mesquite) invasion and clearing on vegetation species composition and diversity in semi-arid Nama-Karoo rangeland, South Africa, African Journal of Range \& Forage Science, 33:2, 101-110, DOI: 10.2989/10220119.2016.1184181

To link to this article: http://dx.doi.org/10.2989/10220119.2016.1184181

+ View supplementary material $₫$

\section{册Published online: 04 Jul 2016.}

\section{Submit your article to this journal $₫$}

山 Article views: 21

Q View related articles $\asymp$

\section{View Crossmark data}




\title{
Impact of Prosopis (mesquite) invasion and clearing on vegetation species composition and diversity in semi-arid Nama-Karoo rangeland, South Africa
}

\author{
Thabisisani Ndhlovu ${ }^{1 *}$, Suzanne J Milton² and Karen J Esler ${ }^{3}$ \\ ${ }^{1}$ Department of Conservation Ecology and Entomology, Stellenbosch University, Stellenbosch, South Africa \\ ${ }^{2}$ DST/NRF Centre of Excellence at the Percy FitzPatrick Institute of African Ornithology, University of Cape Town, Cape \\ Town, South Africa \\ ${ }^{3}$ Centre for Invasion Biology and Department of Conservation Ecology and Entomology, Stellenbosch University, Stellenbosch, \\ South Africa \\ *Corresponding author, email: thabisisani.ndhlovu@gmail.com
}

\begin{abstract}
The Nama-Karoo biome occupies $28 \%$ of South Africa's land area. Alien leguminous trees of the genus Prosopis have invaded large tracts of Nama-Karoo rangeland. We evaluated the impact of Prosopis invasion and clearing on vegetation species composition and diversity (alien and indigenous species richness and cover) in Nama-Karoo rangeland on two sheep farms in the Beaufort West district of the Western Cape province of South Africa. Our results suggest that Prosopis invasion and clearing can significantly change Nama-Karoo rangeland species composition. Invasion and clearing appear to have no effect on alien species richness. Invasion, however, increases alien species cover, while clearing restores it to pre-invasion levels. In contrast, invasion reduces indigenous species richness while clearing restores it to pre-invasion levels. Invasion appears to have no effect on indigenous species cover. This lack of effect appears to be the serendipitous result of a site-specific trade-off between a decline in cover of grasses that are negatively affected by Prosopis invasion and a concomitant increase in the cover of positively affected grasses. Clearing increases indigenous species cover to above pre-invasion levels. The higher than usual indigenous species cover after clearing could be a transient legacy of Prosopis soil nutrient enrichment.
\end{abstract}

Keywords: invasive plants - exotic, Nama-Karoo, plant community ecology, rehabilitation, semi-arid

Online supplementary information: Supporting information for this paper is available as online supplementary material at http://dx.doi.org/10.2989/10220119.2016.1184181

Introduction

Alien plants have invaded large areas (>10 million ha) of South Africa (Binns et al. 2001; van Wilgen et al. 2001). Much of the affected area supports natural and semi-natural ecosystems of environmental and socio-economic importance (Le Maitre et al. 2000; Milton et al. 2003; Richardson and van Wilgen 2004; van Wilgen et al. 2008). Invasive alien plants (IAPs) are thought to have eroded the natural capital (i.e. the stock of natural resources, such as biodiversity, soils and hydrological cycles, that enable ecosystems to provide goods and services into the future) of these critical ecosystems by compromising their structure and function (Le Maitre et al. 2000; Milton et al. 2003; Richardson and van Wilgen 2004; van Wilgen et al. 2008). As a result, much effort has been expended in South Africa on controlling and mitigating the spread and impact of IAPs and, increasingly, on restoring IAP-damaged ecosystems (Richardson and van Wilgen 2004; Blignaut 2010; van Wilgen et al. 2012).

The Nama-Karoo biome occupies 28\% (346 100 km²) of South Africa's land area and covers much of the central and western regions of the country (Palmer and Hoffman 1997; Hoffman 2000; Suttie et al. 2005). Large tracts (>180 $000 \mathrm{~km}^{2}$ ) of Nama-Karoo rangeland have been invaded by alien leguminous trees of the genus Prosopis (Richardson and van Wilgen 2004). The trees, which are indigenous to the Americas, were introduced into the area in the late 1880 s to provide shade, fodder and fuel wood (Zimmermann 1991; Palmer and Hoffman 1997; Richardson and van Wilgen 2004; Zimmermann and Pasiecznik 2005). However, their introduction has had serious negative environmental impacts (Steenkamp and Chown 1996; Richardson et al. 2000; Dean et al. 2002; Richardson and van Wilgen 2004; Zimmermann and Pasiecznik 2005; Ndhlovu 2011; Ndhlovu et al. 2011; Dzikiti et al. 2013; Schachtschneider and February 2013; Shackleton et al. 2015a, 2015b; Ndhlovu et al. 2016). In many areas, invasive Prosopis trees have coalesced to form dense thorny thickets that are thought to have displaced indigenous plants and substantially altered rangeland vegetation composition, diversity and structure (Richardson et al. 2000; Richardson and van Wilgen 2004). Like many other plant invasions in South Africa's sparsely populated arid regions (Milton and Dean 1998), the processes and impacts of Prosopis invasion in the Nama-Karoo have not been adequately studied.

Large areas of the Nama-Karoo have been cleared of Prosopis trees under a government-run IAP control programme dubbed 'Working for Water' (WfW) (Zimmermann and Pasiecznik 2005), whose primary aim is to secure South Africa's water resources by clearing IAPs from major watersheds (Le Maitre et al. 2000; Binns et al. 2001; Le Maitre et al. 2002). Although the justification for the WfW programme has been explicitly based on its potential to 
deliver socio-economic benefits through increased water supply and employment (van Wilgen et al. 1998; Binns et al. 2001; Anon 2006; Hope 2006), there is an implicit assumption that IAP clearings will also result in the restoration of ecosystem structure and function in affected areas (Esler et al. 2008; Holmes et al. 2008). Very few studies (e.g. Saayman and Botha 2007; Ndhlovu et al. 2011, 2016) have empirically tested this assumption in Nama-Karoo rangeland. None has focused on the impact of Prosopis invasion and clearing on vegetation species composition and diversity.

We evaluated the impact of Prosopis invasion ( $15 \%$ canopy cover) and clearing on vegetation species composition and diversity in Nama-Karoo rangeland on two sheep farms in the Beaufort West district of the Western Cape province of South Africa. Our objectives were to (1) determine the impacts of invasion and clearing on vegetation species composition and diversity (alien and indigenous species richness and cover) and (2) deduce the vegetation processes that may have underlain the impacts. To achieve these objectives, we addressed the following questions:

- How did Prosopis invasion and clearing impact vegetation composition and alien and indigenous species richness and cover in affected rangeland?

- What changes in plant species presence and cover underlay the observed impacts?

- What vegetation processes could have underlain the observed changes?

While we expected Prosopis invasion and clearing to significantly impact overall plant species composition and diversity at our study site, we had no a priori hypotheses concerning underlying species changes. Although Prosopis invasion and control have been shown to affect vegetation composition and diversity across a range of ecosystems (e.g. Kincaid et al. 1959; Cable and Tschirley 1961; Scifres et al. 1974; Scifres and Polk 1974; Cable 1976; Tiedemann and Klemmedson 1977; Martin and Morton 1993; Ruthven 2001; Dean et al. 2002; Tiedemann and Klemmedson 2004; McClaran and Angell 2006; Pease et al. 2006; Simmons et al. 2008; Schachtschneider and February 2013; Shackleton et al. 2015a, 2015b), our study was the first to attempt an evaluation of plant species responses in Nama-Karoo rangeland. We, therefore, lacked sufficient a priori information to construct specific hypotheses about species-level responses. As a result we adopted an exploratory approach and conducted our study without pre-conceived hypotheses.

\section{Materials and methods}

\section{Study site}

Our study was conducted on the farms De Hoop (32 $\left.2^{\circ} 10^{\prime} 13^{\prime \prime} \mathrm{S}, 22^{\circ} 47^{\prime} 5^{\prime \prime} \mathrm{E}\right)$ and Brandwag (32'11'36" S, $\left.22^{\circ} 48^{\prime} 19^{\prime \prime} \mathrm{E}\right)$, located about $30 \mathrm{~km}$ north-east of the town of Beaufort West in the Western Cape province of South Africa. De Hoop farm was still completely covered by stands of invasive Prosopis trees at the time of our study (June and October 2009), whereas the trees had been completely cleared from the neighbouring Brandwag farm. Prosopis trees were cleared from Brandwag farm by WfW teams between 2003 and 2005. As it was difficult to determine the exact years when clearing occurred, clearing impacts were considered to relate to conditions 4-6 years after clearing. Clearing consisted of felling trees at $100 \mathrm{~mm}$ above ground level and treating stumps with Garlon ${ }^{\circledR} 4$ herbicide (triclopyr ester) at a $4 \%$ dilution with diesel. Felled wood and branches were left lying in the field and no further interventions were taken to aid the recovery of indigenous vegetation. Both farms were stocked with sheep and the vegetation showed signs of degradation from overgrazing. Information on the grazing histories of the farms was unavailable. Details on vegetation, soils and climate at the study site are provided elsewhere (Ndhlovu 2011; Ndhlovu et al. 2011, 2016). We used the generic term Prosopis in our study because of the uncertainty surrounding Prosopis classification to species level in South Africa (see Ndhlovu et al. 2011; Mazibuko 2012).

\section{Sampling and data collection}

Sampling and data collection was conducted on Prosopis invaded $(n=2)$, cleared $(n=3)$ and uninvaded $(n=5)$ sites within Brandwag and De Hoop farms. The sites were specifically selected to be as environmentally uniform as possible (see Ndhlovu et al. 2016). Cleared sites were restricted to Brandwag and invaded to De Hoop, while uninvaded sites occured across both farms. Invaded and cleared sites had similar Prosopis tree size-class distributions (determined from basal diameters of standing trees in invaded sites and tree stumps in cleared sites). The average Prosopis tree basal diameter was $110 \mathrm{~mm}$ across the sites. Invaded sites had an average Prosopis cover of approximately 15\%. All sites were part of the farmers' day-to-day management of livestock and exhibited similar signs of severe overgrazing. As uninvaded sites from Brandwag and De Hoop did not exhibit significant compositional difference, management differences between the two farms were considered to be insignificant. Plant species cover estimates at each of the sites were obtained using ten $50 \mathrm{~m}$ line-point intercepts (see Herrick et al. 2005 and Ndhlovu et al. 2016 for details). Species cover referred to the cover of the upper layer of each plant species independent of overhanging cover of other species (Herrick et al. 2005; Fehmi 2010) and differed from canopy and basal cover (the proportion of each species at the uppermost and lowermost surfaces of the vegetation) measured in Ndhlovu et al. (2016).

\section{Data analysis}

Alien and indigenous species cover

Alien and indigenous species cover per transect were calculated by summing the percent species cover of the individual alien and indigenous species that occurred along transects. Likewise, percent plant functional type cover per transect were determined by summing the individual percent species cover of species classified into six functional groups (viz. annual grass, perennial grass, annual herb, perennial herb, succulent shrub and non-succulent shrub). Mean alien and indigenous cover in uninvaded, invaded and cleared sites was calculated by averaging transect alien and indigenous species cover. Given that the percent cover of individual plant species was evaluated independently, grouped species cover could exceed $100 \%$ (see Fehmi 2010). Species were classified as alien or indigenous and grouped into functional types using published descriptions (Meredith 1955; Le Roux et al. 
1994; Shearing and van Heerden 1994; Esler et al. 2006). The publications were also used to gather information on other species ecological attributes such as dispersal mode, habitat preference and interspecific competitiveness. Prosopis was excluded from all data sets.

\section{Impact of invasion and clearing on vegetation composition} The impact of invasion and clearing on vegetation composition was evaluated by comparing plant species composition in uninvaded, invaded and cleared sites. Differences in species composition between uninvaded vs invaded, invaded vs cleared and uninvaded vs cleared sites were taken to reflect invasion and clearing impacts. Uninvaded sites were regarded as representing pre-invasion states. Non-metric multidimensional scaling (NMDS; two dimensions, Bray-Curtis distances) was used to visually represent compositional relationships between sites, whereas statistical significance was assessed using one-way analysis of similarities (ANOSIM; sequential Bonferroni significance, 10000 permutations, Bray-Curtis distances). NMDS is an ordination method that organises samples in multidimensional space according to compositional similarity (Kruskal 1964). The NMDS results are displayed as two-dimensional diagrams in which compositionally similar sites are plotted near each other and dissimilar sites farther apart. ANOSIM is a non-parametric procedure that tests for significant differences between two or more multivariate groups (Clarke 1993). The NMDS analyses were conducted using the vegan package (Oksanen et al. 2015) in $R$ ( $R$ Core Team 2014). The ANOSIM analyses were conducted in the Paleontological Statistics Software Package for Education and Data Analysis (PAST; Hammer et al. 2001).

The vegetation dynamics that underlay species composition changes during invasion and clearing were deduced from differences in the mean percent cover of the species responsible for most of the compositional differences between uninvaded, invaded and cleared sites. Differences in mean percent cover of species in uninvaded vs invaded, invaded vs cleared and uninvaded vs cleared sites were taken to be the result (and thus indicative) of plant species composition changes caused by Prosopis invasion and clearing. Plant species responsible for most (i.e. $\sim 90 \%$ ) of the compositional differences between sites were identified and ranked using similarity of percentage (SIMPER) analysis. SIMPER is a multivariate technique that ranks taxa according to their contribution to Bray-Curtis dissimilarities between contrasted groups (Clarke 1993). The SIMPER analyses were conducted in PAST.

Impact of invasion and clearing on alien and indigenous species richness and cover

The impact of invasion and clearing on alien and indigenous species richness was determined by comparing alien (other than Prosopis) and indigenous species richness in uninvaded vs invaded, invaded vs cleared and uninvaded vs cleared sites. Comparisons were made using the Compare Diversities module in PAST (1 000 bootstrap randomisations; Hammer et al. 2001). Compare Diversities computes a number of diversity indices for paired samples and statistically compares them through permutation or bootstrap randomisation (Hammer et al. 2001). Species frequency per site data (i.e. number of transects per site along which a species was present) were used to conduct richness comparisons.

Transect data from uninvaded, invaded and cleared sites were tested for sampling saturation (Magurran 2004) prior to species richness estimation using species accumulation curves (Mao tau sample-based rarefaction; Colwell et al. 2004) generated using PAST. The curves demonstrated that, although additional species would have been discovered with more transects, the available data were sufficient to determine differences in species richness between the sites (Figure 1).

The minimum species richness estimates calculated from sample-based line point intercept data (Herrick et al. 2005) were supplemented by statistically estimated species richness (minimum predicted numbers of species based on the sample data; Magurran 2004). The estimated species richness values were calculated using the program EstimateS version 8 (10 000 randomisations with default settings; RK Colwell, available at http://purl.oclc.org/ estimates). Three estimators of species richness were used: incidence-based coverage estimator (ICE; Chao et al. 2000), Chao2 richness estimator (Chao 1984), and the second-order jackknife richness estimator (Jackknife 2; Burnham and Overton 1979). Three richness estimators were used concurrently to cross-check (triangulate) results (see Yurkov et al. 2011 for the rationale behind triangulating richness estimators).

Presence-absence data derived from alien and indigenous species cover were used to determine statistically estimated species richness. The impacts of invasion and clearing on estimated alien and indigenous species richness were evaluated by comparing means of estimated richness in uninvaded vs invaded, invaded vs cleared and uninvaded vs cleared sites. The significance of the differences was assessed using the one-way ANOVA via randomisation test in the software package Resampling Procedures 1.3 (10 000 randomisations; DC Howell, University of Vermont, available at http://www.uvm.edu/dhowell/statPages/Resampling/

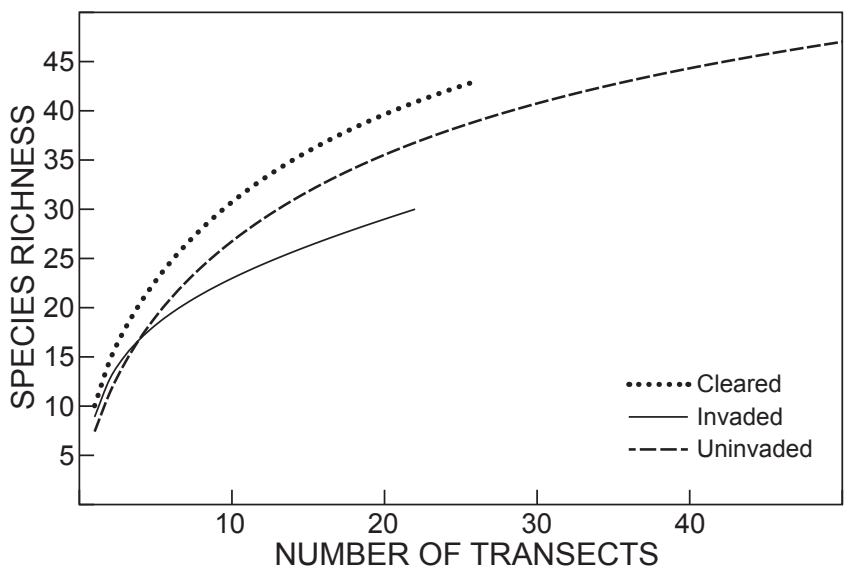

Figure 1: Species accumulation curves (Mao tau sample-based rarefaction) for uninvaded $(n=5)$, invaded $(n=2)$ and cleared $(n=3)$ sites near Beaufort West in the Western Cape province of South Africa 
Resampling.html). Differences were considered significant at $p \leq 0.05$. Non-parametric randomisation (Manly 1997) was used because the data were non-normal. Normality was tested using the Shapiro-Wilk test (Shapiro and Wilk 1965). Variation around means was expressed in standard errors.

The effects of Prosopis invasion and clearing on the abundance of alien and indigenous species were determined by comparing mean alien and indigenous species cover in uninvaded, invaded and cleared sites. The vegetation dynamics that underlay the observed alien and indigenous species cover changes were deduced from differences in mean alien and indigenous plant functional type and species cover between the sites. Cover differences between uninvaded vs invaded, invaded vs cleared and uninvaded vs cleared sites were taken to represent the impacts of invasion and clearing. Alien and indigenous plant functional types whose mean cover differences were significantly different were analysed to species level. The relative magnitudes of the vegetation changes were evaluated by considering the extents of the cover changes that were associated with them. Means and standard errors were calculated using the program PAST, whereas the significance of differences in plant functional type and species cover was assessed using Resampling Procedures 1.3 (one-way ANOVA, 10000 randomisations).

\section{Adjustments for multiple comparisons}

No adjustments for multiple comparisons were conducted for analyses at species level. As our study was exploratory (i.e. data were collected without pre-specified hypotheses), we considered multiple comparison adjustments unnecessary and even counterproductive (see Bender and Lange 2001). Adjustments for multiple comparisons reduce the number of false positives (incorrectly rejected null hypotheses) during statistical tests (MacDonald 2009). However, the adjustments also simultaneously increase the number of false negatives (incorrectly accepted null hypotheses; MacDonald 2009). As a result, when multiple comparison adjustments are applied to large data sets, such as in our study, the power of statistical tests to detect real differences may become unacceptably low (Bender and Lange 2001; MacDonald 2009). In such situations, it is usually more costly to use multiple-comparison procedures that ignore real differences than to use procedures that occasionally misclassify non-significant differences (Bender and Lange 2001). The cost of a false positive is just a few more experiments, while that of a false negative could entail missing a hugely important discovery (MacDonald 2009). This approach is, however, not free from controversy and is currently an area of active research (MacDonald 2009).

\section{Results}

\section{Impact of invasion and clearing on vegetation composition}

As expected, Prosopis invasion and clearing altered plant species composition in affected rangeland. The composition changes were, however, not substantial. Clearing caused the greatest change in species composition. Plant species composition in cleared rangeland had not reverted to the pre-invasion state after more than four years. There were significant dissimilarities in species composition between uninvaded vs invaded $(R=0.21, P<0.001)$, invaded vs cleared $(R=0.31, P<0.001)$ and uninvaded vs cleared sites $(R=0.27, P<0.001)$. The greatest dissimilarity in species composition was between invaded vs cleared sites (overall average dissimilarity $=62 \%$ ) followed by uninvaded vs invaded (overall average dissimilarity $=57 \%$ ) and uninvaded vs cleared (overall average dissimilarity = $56 \%$ ) sites. The overall average dissimilarities (Bray-Curtis dissimilarity measures*100) were derived from pair-wise SIMPER group comparisons (Clarke 1993). Although the 95\% NMDS confidence ellipses around invaded (II) and cleared (III) transects were separated from each other, there was some overlap between the two and uninvaded (I) transects (Figure 2). The stress value for the NMDS was relatively high (0.231; Figure 2$)$, signifying that although the ordination results were generally usable, too much credence was not, however, to be placed on their details (see McCune et al. 2002).

Most of the change in species composition during invasion was driven by declines in the cover of the annual grass Aristida adscensionis L. and the non-succulent shrub Pentzia incana (Thunb.) Kuntze and increases in the cover of the annual and perennial grasses Chloris virgata Sw. and Cynodon dactylon (L.) Pers. (Supplementary Table S1). Minor compositional changes were linked to reductions in the cover of the non-succulent shrubs Felicia muricata (Thunb.) Nees and Rosenia humilis (Less.) K.Bremer and increases in the cover of the annual grass Setaria verticillata (L.) P.Beauv. and the non-succulent shrubs Lycium cinereum Thunb., Salsola tuberculata Fenzl ex Moq., Atriplex lindleyi Moq., Bassia salsoloides (Fenzl) A.J.Scott, Lycium prunus-spinosa Dunal and Salsola calluna Drege (Supplementary Table S1). Invasion displaced the annual grass Tragus berteronianus Schult. and facilitated the establishment of the non-succulent shrub Pentzia lanata Hutch. (Supplementary Table S1).

Plant species compositional change after clearing was driven mainly by increases in the cover of the annual grass $A$. adscensionis, the non-succulent shrub $P$. incana, and the perennial grasses Eragrostis obtusa Munro ex Ficalho \& Hiern and C. dactylon (Supplementary Table S2). Other minor changes included increases in cover of the annual grasses $S$. verticillata, the perennial grass Eragrostis lehmanniana Nees and the non-succulent shrubs, $L$. cinereum and $F$. muricata, and declines in the annual grass $C$. virgata and the non-succulent shrubs P. lanata, L. prunus-spinosa, A. lindleyi, B. salsoloides, and $S$. tuberculata (Supplementary Table S2). Clearance facilitated the re-establishment of the annual and perennial grasses $T$. berteronianus and E. obtusa (Supplementary Table S2).

Cleared rangeland differed mainly from uninvaded rangeland in having a lower cover of the non-succulent shrub $P$. incana and higher cover of the annual grass $A$. adscensionis and the perennial grasses E. obtusa and $C$. dactylon (Supplementary Table S3). Other minor differences included higher cover of the annual grasses C. virgata, $T$. berteron-ianus and $S$. verticillata, the perennial grass E. lehmanniana, the alien annual herb Medicago laciniata (L.) Mill. and the non-succulent shrubs F. muricata, 


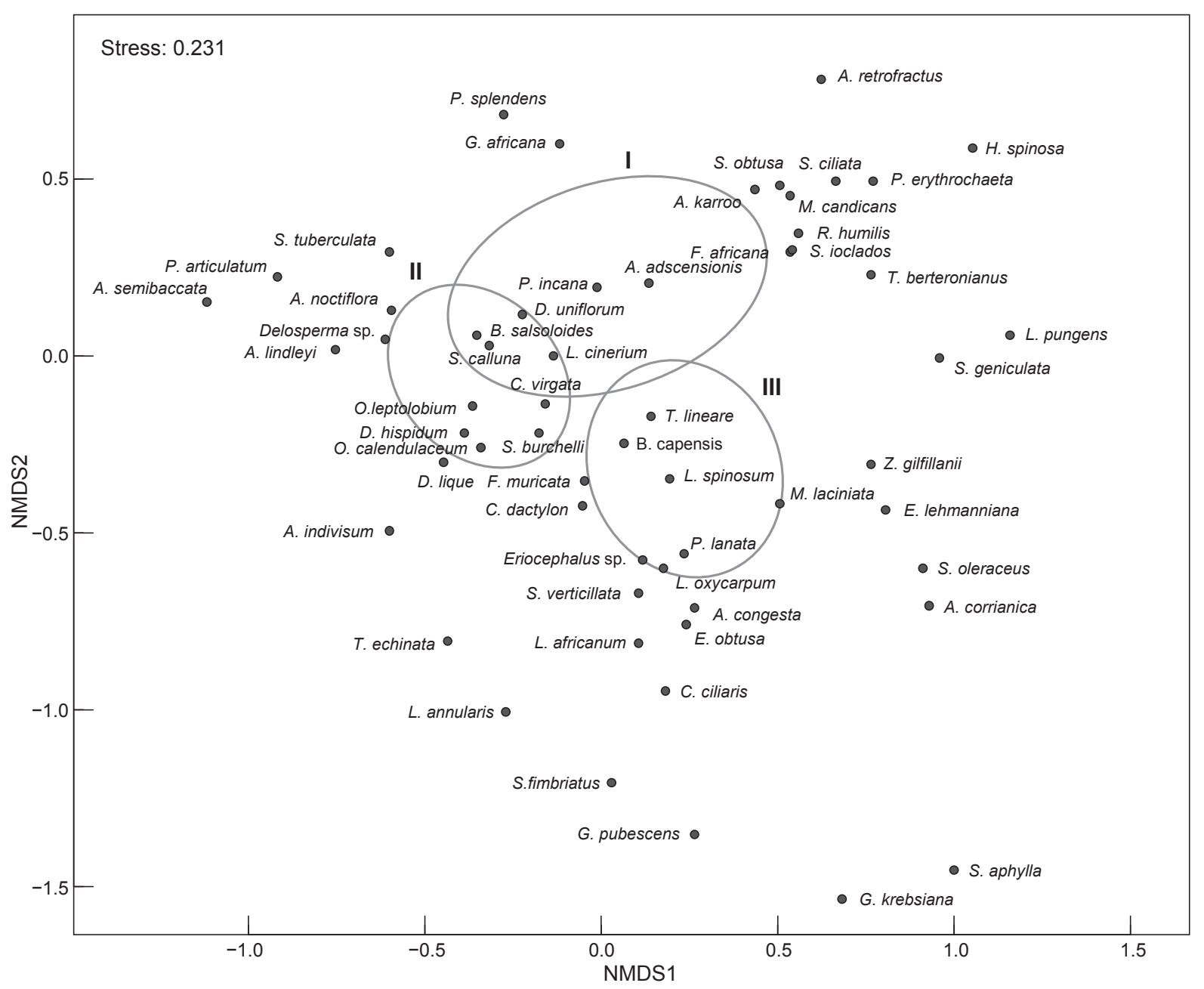

Figure 2: Two-dimensional non-metric multidimensional scaling (NMDS) plot showing plant species composition relationships between uninvaded $(n=5)$, invaded $(n=2)$ and cleared $(n=3)$ sites near Beaufort West in the Western Cape province of South Africa. Also shown are $95 \%$ confidence ellipses ( $\mathrm{I}=$ uninvaded, $\mathrm{II}$ = invaded and III = cleared)

L. cinereum, L. prunus-spinosa, L. oxycarpum and Asparagus retrofractus L., and lower cover of non-succulent shrubs $R$. humilis and $S$. tuberculata (Supplementary Table S3).

\section{Impact of invasion and clearing on alien species richness and cover}

Invasion did not change the richness of alien species (three to four species) but increased their cover from $0.44 \%$ to $2 \%$ (Figure 3 ). Clearing reduced alien species richness by one to two species and cover from $2 \%$ to $1 \%$ (Figure 3 ). Alien species richness declined to below pre-invasion levels after clearing while alien species cover declined to pre-invasion levels. There was no significant difference in alien species richness (ICE richness $F=2.24, P=0.136$; Chao2 richness $F=0.05, P=0.839$; Jackknife 2 richness $F=1.10, P=0.292)$ between uninvaded and invaded sites (Table 1). Mean alien species cover in invaded sites $(2.18 \pm$ $0.49 \%)$ was significantly higher $(\mathrm{F}=20.08, P<0.001)$ than in uninvaded sites $(0.44 \pm 0.14 \%)$. Cleared sites had signifi-cantly lower mean alien species cover $(1.08 \pm 0.35 \%$; $F=3.47, P=0.051)$ than invaded sites. Cleared sites had significantly lower alien species richness (ICE richness $F=90.51, P<0.001$; Chao2 richness $F=25.05, P<0.001$; Jackknife 2 richness $F=16.53, P<0.001$ ) than invaded sites (Table 1). Cleared sites had significantly fewer alien species (ICE richness $F=15.12, P<0.001$; Chao2 richness $F=28.54, P<0.001$; Jackknife 2 richness $F=18.05$, $P<0.001$ ) than uninvaded sites (Table 1 ).

The gain in alien species cover during invasion and the loss after clearing were linked to increases and declines in cover of the non-succulent shrub $A$. lindleyi. The reduction in alien species cover after clearing was counteracted to a lesser extent by an accompanying increase in the cover of the alien annual herb M. laciniata. The cover of the third alien species, the non-succulent shrub Atriplex semibaccata $\mathrm{R}$.Br., was not affected by invasion or clearing. Mean cover of $A$. lindleyi differed significantly between uninvaded vs invaded $(F=31.369, P<0.001)$ and invaded vs cleared sites $(F=24.763, P<0.001$; Table 1$)$. The mean cover of $M$. laciniata was significantly higher $(F=5.28, P=0.037)$ in cleared than in invaded sites (Supplementary Table S4). There was no significant difference in the mean cover of A. semibaccata between uninvaded and invaded sites 
$(F=1.51, P=0.306)$ and invaded and cleared sites $(F=1.19, P=0.456$; Supplementary Table $S 4)$.

\section{Impact of invasion and clearing on indigenous species richness and cover}

Invasion reduced the richness of indigenous species by six to seven species but did not affect total cover (Figure 3). Clearing increased indigenous species richness by between 10 and 15 species and cover from $65 \%$ to $100 \%$ (Figure 3). Indigenous species richness in cleared rangeland reverted to the pre-invasion level (between 40 and 47 species), whereas cover remained $36 \%$ higher than the pre-invasion level (i.e. 65\%) after more than four years after clearing (Figure 3 ). Indigenous species richness was significantly lower (observed richness $P<0.001$; ICE richness $F=148.48, P<0.001$; Chao2 richness $F=14.76$, $P<0.001$; Jackknife 2 richness $F=35.59, P<0.001$ ) in invaded than uninvaded sites (Table 1). There was no significant difference $(F=0.00, \mathrm{P}<1.000)$ in mean indigenous species cover between uninvaded (64.60 \pm $4.09 \%)$ and invaded sites (64.64 $\pm 7.80 \%)$. Indigenous species richness was significantly higher (observed

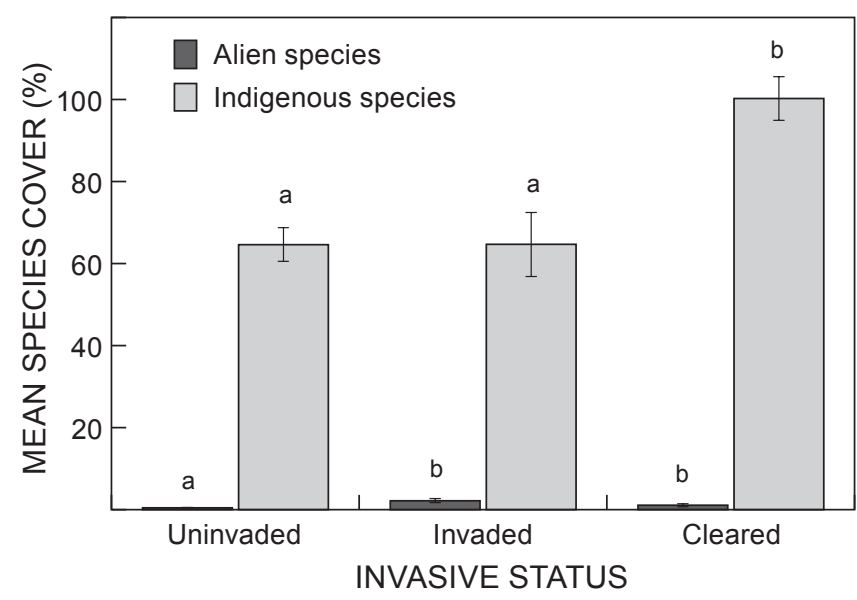

Figure 3: Mean percent cover $( \pm S E)$ of alien and indigenous plant species in uninvaded $(n=5)$, invaded $(n=2)$ and cleared $(n=3)$ sites near Beaufort West in the Western Cape province of South Africa. Significance was determined by one-way ANOVA via randomisation richness $P<0.001$; ICE richness $F=90.51, P<0.001$; Chao2 richness $F=25.50, P<0.001$; Jackknife 2 richness $F=16.53 P<0.001$ ) in cleared than invaded sites (Table 1). Mean indigenous species cover in cleared sites (100.23 \pm $5.31 \%)$ was significantly higher $(F=14.95, \mathrm{P}<0.001)$ than in invaded sites. There was no significant difference (observed richness $P=0.356$; ICE richness $F=0.03$, $P=0.866$; Chao2 richness $F=3.64, P=0.059$; Jackknife 2 richness $F=1.18, P=0.292$ ) in indigenous species richness in uninvaded and cleared sites (Table 1). Cleared sites had mean indigenous species cover significantly higher $(F=27.06, P<0.001)$ than uninvaded sites.

There was no change in the cover of indigenous grasses, herbs and shrubs during invasion. The increase in indigenous species cover after clearing was linked to increases in cover of the annual grasses $A$. adscensionis and $T$. berteronianus and, to a lesser extent, the perennial grasses E. obtusa and E. lehmanniana. Indigenous species cover in cleared rangeland was higher than the pre-invasion level as a result of higher cover of the annual grasses $A$. adscensionis, $C$. virgata and $S$. verticillata, perennial grasses $E$. obtusa and $C$. dactylon and the perennial herb Galenia pubescens (Eckl. \& Zeyh.) Druce. There was no significant difference in mean annual grass $(F=0.04, P=0.857)$, perennial grass $(F=1.67$, $P=0.212)$, annual herb $(F=0.17, P=0.753)$, perennial herb $(F=1.15, P=0.356)$, succulent shrub $(F=0.00$, $P=1.000)$, and non-succulent shrub cover $(F=0.56$ $P=0.466$ ) between uninvaded and invaded sites (Supplementary Table S5). Only indigenous annual and perennial grasses had significantly different mean cover $(F=10.88, P=0.079, F=13.58, P<0.001)$ in invaded and cleared sites (Supplementary Table S6). Of the annual and perennial grasses present in the study sites A. adscensionis $(F=18.42, P<0.001), T$ berteronianus $(F=6.99, P=0.004)$, E. obtusa $(F=16.14, P<0.001)$ and $E$. lehmanniana $(F=9.38, P<0.001)$ had significantly different mean cover in invaded and cleared sites (Supplementary Table S6). Indigenous annual grasses $(F=2.30, P<0.001)$, perennial grasses $(F=40.33$, $P<0.001)$ and perennial herbs $(F=4.97, P=0.052)$ had significantly different cover in uninvaded and cleared sites (Supplementary Table S7). At species level, the annual grasses $A$. adscensionis $(F=11.95, P=0.001)$, C. virgata $(F=5.58, P=0.005)$ and $S$. verticillata $(F=7.07$,

Table 1: Comparison of plant species richness in uninvaded $(n=5)$, invaded $(n=2)$ and cleared sites $(n=3)$ sites near Beaufort West in the Western Cape province of South Africa. Variation around mean estimated species richness is expressed in standard errors. Different superscript letters within a row denote significantly different values at $P \leq 0.05$ (one-way ANOVA via randomisation)

\begin{tabular}{lccc}
\hline Species richness estimator & Uninvaded & Invaded & Cleared \\
\hline Alien species & & & \\
Observed richness & 3 & 3 & 2 \\
ICE estimated richness & $3 \pm 0.14^{\mathrm{a}}$ & $3 \pm 0.25^{\mathrm{a}}$ & $2 \pm 0.15^{\mathrm{b}}$ \\
Chao 2 estimated richness & $2 \pm 0.11^{\mathrm{a}}$ & $2 \pm 0.19^{\mathrm{a}}$ & $1 \pm 0.08^{\mathrm{b}}$ \\
Jackknife 2 estimated richness & $3 \pm 0.15^{\mathrm{a}}$ & $4 \pm 0.39^{\mathrm{a}}$ & $2 \pm 0.19^{\mathrm{b}}$ \\
Indigenous species & & & \\
Observed richness & $43^{\mathrm{a}}$ & $27^{\mathrm{b}}$ & $40^{\mathrm{a}}$ \\
ICE estimated richness & $46 \pm 0.70^{\mathrm{a}}$ & $31 \pm 1.12^{\mathrm{b}}$ & $46 \pm 1.17^{\mathrm{a}}$ \\
Chao 2 estimated richness & $43 \pm 0.98^{\mathrm{a}}$ & $36 \pm 1.75^{\mathrm{b}}$ & $46 \pm 1.17^{\mathrm{a}}$ \\
Jackknife 2 estimated richness & $47 \pm 1.65^{\mathrm{a}}$ & $30 \pm 2.10^{\mathrm{b}}$ & $44 \pm 2.68^{\mathrm{a}}$ \\
\hline
\end{tabular}


$P=0.009)$, perennial grasses $E$. obtusa $(F=18.42$ $P<0.001)$ and $C$. dactylon $(F=18.42, P<0.001)$ and the perennial herb $G$. pubescens $(F=18.42, P<0.001)$ had significantly different mean cover in uninvaded and cleared sites (Supplementary Table S7).

\section{Discussion}

Several studies have shown that Prosopis invasion and clearing can strongly influence the composition, diversity and structure of understory or adjacent vegetation (e.g. Kincaid et al. 1959; Cable and Tschirley 1961; Scifres et al. 1974; Scifres and Polk 1974; Cable 1976; Tiedemann and Klemmedson 1977; Martin and Morton 1993; Ruthven 2001; Dean et al. 2002; Tiedemann and Klemmedson 2004; McClaran and Angell 2006; Pease et al. 2006; Simmons et al. 2008; Schachtschneider and February 2013; Shackleton et al. 2015a, 2015b). Most of the studies were conducted in semi-arid, arid and desert rangelands in the southern and south-western USA. Our study is the first to report on the impact of Prosopis invasion and clearing on vegetation species composition and diversity in South Africa's semi-arid Nama-Karoo rangeland. It augments our earlier work on the impact of Prosopis invasion and clearing on Nama-Karoo rangeland grazing capacity (Ndhlovu et al. 2011) and vegetation soil cover (Ndhlovu et al. 2016).

\section{Impact of invasion and clearing on plant species composition}

Our results confirmed that Prosopis invasion and clearing could alter plant species composition in Nama-Karoo rangeland. Species composition change during invasion involved concomitant increases and decreases in cover of different grass and shrub species. This was probably because, while Prosopis trees generally compete with plants in their understory and neighbourhood for light, moisture and nutrients (Tiedemann and Klemmedson 1977; Meyer and Bovey 1986), they also act as nurse plants for other subcanopy species by creating ideal microhabitats via nitrogen fixation and shading (Ruthven 2001).

For example, while the decline in the annual grass A. adscensionis during invasion was most likely caused by competition for light (shading) from invading Prosopis trees the increases in the annual grasses $C$. virgata and $S$. verticillata, the perennial grass $C$. dactylon and the non-succulent shrubs $A$. lindleyi and $S$. tuberculata were most probably in response to the establishment of favourable environmental conditions in the subcanopies and neighbourhoods of the trees. Aristida adscensionis performs poorly in shade (Varshney 1968), whereas C. virgata, C. dactylon and the alien non-succulent shrub A. lindleyi tolerate shade and are hardy colonisers of bare or disturbed soil (Le Roux et al. 1994; Shearing and van Heerden 1994; Esler et al. 2006). Setaria verticillata thrives in nitrogen-enriched shaded environments and S. tuberculata can withstand low moisture conditions (Le Roux et al. 1994; Shearing and van Heerden 1994; Esler et al. 2006). Prosopis trees, by denuding their neighbourhood of vegetation cover (Gibbens et al. 1986), enriching their subcanopy with nitrogen and other soil nutrients (Tiedemann and Klemmedson 1973; Barth and Klemmedson 1982; Gadzia and Ludwig 1983; Klemmedson and Tiedemann 1986; Frias-Hernandez et al. 1999; Geesing et al. 2000; Reyes-Reyes et al. 2002) and lowering moisture content in surrounding soil (Tiedemann and Klemmedson 1973, 1977; Jacoby et al. 1982), provide ideal conditions for the establishment and increase of such species. The increase in cover of $S$. verticillata would have likely been tempered by lowered soil moisture as the annual grass thrives in less dry conditions (Rutherford et al. 2014). The seeds of these species are dispersed on animal hair or in dung, and were also probably concentrated beneath Prosopis trees by livestock resting in the shade of canopies. Similar patterns in the distribution of zoochoric plant species have been observed in other arid areas (e.g. Milton and Dean 1995).

Prosopis trees could have caused some of the species composition changes that occurred during invasion indirectly. The loss of $A$. adscensionis as a result of shading by Prosopis trees, for example, could have intensified grazing pressure on the non-succulent shrub $P$. incana and led to its decline. Pentzia incana, similar to $A$. adscensionis, is resilient to heavy grazing and is an important component of forage production in overgrazed rangeland (Le Roux et al. 1994; Shearing and van Heerden 1994; Esler et al. 2006). Likewise, the non-succulent shrubs $L$. cinereum and $L$. spinosum, which produce small edible fruits, could have increased as a result of increased dispersal by birds perching on invading Prosopis trees (see Dean et al. 2002; Milton et al. 2007; Iponga et al. 2009). However, this advantage could have been limited as the steep angles of Prosopis canopies are thought to discourage maximum utilisation of the trees by birds (Dean et al. 2002).

The increases in the annual grasses $A$. adscensionis, $S$. verticillata, $T$. berteronianus, the perennial grasses E. obtusa, C. dactylon, E. lehmanniana and the nonsucculent shrubs $P$. incana, $L$. cinereum and $F$. muricata that drove species composition change after clearing were most likely in response to the release of the species from Prosopis competition. In the case of the annual grasses $A$. adscensionis and $T$. berteronianus, and the perennial grasses $E$. obtusa and $E$. lehmanniana, which are shade intolerant (Varshney 1968; Klink and Joly 1989; Veenendaal et al. 1993), increases in cover after clearing were most certainly linked to cessation of shading. Increase in $S$. verticillata was most likely linked to increase in soil moisture following Prosopis clearing. This annual grass prefers wetter conditions (Rutherford et al. 2014). The increase in cover of the grasses could have reduced the grazing pressure on the comparatively less palatable non-succulent shrubs $P$. incana and $F$. muricata and led to their increase. In addition, the increase in cover of the above-mentioned grasses could have led to the declines in the annual grass $C$. virgata, the alien herb $A$. lindleyi and the non-succulent shrubs $P$. lanata, L. prunus-spinosa, $B$. salsoloides and $S$. tuberculata through increased interspecific competition for soil moisture. The annual grass C. virgata and the alien herb $A$. lindleyi are poor competitors that naturally occur in disturbed or bare areas denuded of competing plants (Le Roux et al. 1994; Shearing and van Heerden 1994; Esler et al. 2006). Soil moisture is the most important limiting factor in the Nama-Karoo (Milton 1995). 
The higher-than-usual grass cover in cleared rangeland was probably a legacy of Prosopis soil nutrient enrichment. Prosopis trees accumulate soil nutrients such as carbon, nitrogen, magnesium, potassium and phosphorous under their canopies (Tiedemann and Klemmedson 1973; Frias-Hernandez et al. 1999; Geesing et al. 2000; Reyes-Reyes et al. 2002). Non-succulent shrubs could have declined in response to increased competition from grasses. Competition between grasses and woody plants is critical in arid and semi-arid areas (Jacoby et al. 1982; Milton 1995).

\section{Impact of invasion and clearing on alien and indigenous species richness and cover}

The alien flora of the Nama-Karoo reflects the region's climate and economics (Milton and Dean 1998). Unpredictable and quantitatively variable rainfall (Milton and Dean 1998; Esler et al. 2008) has ensured a sparse alien flora while widespread livestock production has resulted in the domination of the flora by introduced livestockdispersed forage species (Milton and Dean 1998). This appears to be also the case at our study site.

Despite being severely degraded, our study site had only three alien species (besides Prosopis), viz. the opportunistic short-lived annual herb $M$. laciniata and the drought-tolerant non-succulent shrubs $A$. lindleyi and $A$. semibaccata. All three invasive alien species were either dispersed unintentionally by livestock or deliberately introduced into the Nama-Karoo to increase livestock carrying capacity. Medicago laciniata was probably unintentionally introduced into the region from Mediterranean North Africa in about 2000 BP with the spread of the herding culture, while the Atriplex species were intentionally imported from Australia and introduced into Nama-Karoo rangeland between 1860 and 1890 (Milton and Dean 1998).

Invasion by Prosopis probably raised alien species cover (i.e. A. lindleyi cover) by directly creating favourable environmental conditions and indirectly altering competition dynamics. Atriplex lindleyi competes poorly against indigenous species (Milton and Dean 1998). However, in cases were indigenous species cover is reduced, either by overgrazing or drought, $A$. lindleyi has been observed to regenerate profusely from seed (Milton and Dean 1998). The cue for $A$. lindleyi seeds to break dormancy is provided by moisture and nitrogen (Milton and Dean 1998). Prosopis trees fix nitrogen (Frias-Hernandez et al. 1999; Geesing et al. 2000; Reyes-Reyes et al. 2002) and considerably reduce indigenous vegetation cover and species richness in Nama-Karoo rangeland through shading and competition for soil moisture and nutrients (Dean et al. 2002; Ndhlovu et al. 2016).

The decrease in A. lindleyi cover after clearing was most likely caused by increased competition from indigenous grasses. Like $A$. lindleyi the indigenous annual grasses $A$. adscensionis and $T$. berteronianus and perennial grasses E. obtusa and E. lehmanniana colonise disturbed ground. This shared adaptation could have led to intense competition between the alien herb and indigenous grass species in the open and disturbed habitat created by Prosopis clearing. The increase in indigenous grass species cover after clearing most likely resulted from the release of the grasses from Prosopis shading and competition for soil moisture. Overall indigenous vegetation cover also increased after clearing, probably also in response to the removal of Prosopis competition.

Invasion appeared to have had no overall effect on indigenous vegetation cover at our study site. However, this lack of overall effect was underlain by a dynamic balance between decline in the cover of grasses negatively affected by Prosopis invasion (e.g. A. adscensionis and $T$. berteronianus) and an accompanying increase in the cover of grass species positively affected by invasion (e.g. C. virgata, S. verticillata and C. dactylon). This dynamic balance was most probably serendipitous and would likely not occur at Prosopis covers higher than at our study site (i.e. greater than 15\% cover; see Ndhlovu et al. 2016).

\section{Conclusion}

Our results suggest that in heavily grazed Nama-Karoo rangeland Prosopis invasion and clearing can significantly change rangeland species composition. Invasion and clearing seem to have no effect on alien species richness, although clearing at our study site resulted in a slight decline in alien species richness. Very few alien species can successfully establish themselves in the Nama-Karoo because of its unpredictable and quantitatively variable rainfall (Milton and Dean 1998; Esler et al. 2008). Invasion, however, seems to increase alien species cover, whereas clearing reduces it to pre-invasion levels. On the other hand, invasion appears to reduce indigenous species richness, whereas clearing restores it to pre-invasion levels. Invasion, however, appears to have no effect on indigenous species cover. This lack of effect could be peculiar to our study site, the result of a site-specific balance between a decline in the cover of grasses negatively affected by Prosopis invasion and the accompanying increase in the cover of positively affected grasses. There are indications that this is not the case at higher Prosopis cover were the negative impacts of the invasive trees on understory vegetation outweigh the positive (see Ndhlovu et al. 2016). Lastly, clearing increases indigenous species cover to above pre-invasion levels. The higher-than-usual indigenous species cover could be the transient legacy of Prosopis soil nutrient enrichment (see Ndhlovu 2011).

Acknowledgements - This work was commissioned and funded by the Water Research Commission (KSA 4: Water Utilisation Use in Agriculture), South Africa and conducted by ASSET Research. We thank Rudi Swart for assisting with fieldwork and Nelmarie Saayman (Western Cape Department of Agriculture) for providing background information about the study site. We are grateful to Werner Koster (Brandwag farm) and Charles de Villiers (De Hoop farm) for granting us access to their properties. We also thank the anonymous reviewers whose comments greatly improved the manuscript.

\section{References}

Anon. 2006. Working for Water in South Africa. Scientist 20: 40.

Barth RC, Klemmedson JO. 1982. Amount and distribution of drymatter nitrogen, and organic carbon in soil-plant systems of mesquite and palo verde. Journal of Range Management 35: 412-418.

Bender R, Lange S. 2001. Adjusting for multiple testing - when and how? Journal of Clinical Epidemiology 54: 343-349.

Binns JA, Illgner PM, Nel EL. 2001. Water shortage, deforestation and development: South Africa's Working for Water programme. 
Land Degradation and Development 12: 341-355.

Blignaut JN. 2010. Restoration in South Africa. Quest 5: 26-30.

Burnham KP, Overton WS. 1979. Robust estimation of population size when capture probabilities vary among animals. Ecology 60: 927-936.

Cable DR. 1976. Twenty years of changes in grass production following mesquite control and reseeding. Journal of Range Management 29: 286-289.

Cable DR, Tschirley FH. 1961. Responses of natural and introduced grasses following aerial spraying of velvet mesquite in southern Arizona. Journal of Range Management 14: 155-159.

Chao A. 1984. Non-parametric estimation of the number of classes in a population. Scandinavian Journal of Statistics 11: 265-270.

Chao A, Hwang WH, Chen YC, Kuo CY. 2000. Estimating the number of shared species in two communities. Statistica Sinica 10: $227-246$.

Clarke KR. 1993. Non-parametric multivariate analysis of changes in community structure. Journal of Ecology 18: 117-143.

Colwell RK, Mao CX, Chang J. 2004. Interpolating, extrapolating, and comparing incidence-based species accumulation curves. Ecology 85: 2717-2727.

Dean WRJ, Anderson MD, Milton SJ, Anderson TA. 2002. Avian assemblages in native Acacia and alien Prosopis drainage line woodland in the Kalahari, South Africa. Journal of Arid Environments 51: 1-19.

Dzikiti S, Schachtschneider K, Naiken V, Gush M, Moses G, Le Maitre DC. 2013. Water relations and the effects of clearing invasive Prosopis trees on groundwater in an arid environment in the Northern Cape, South Africa. Journal of Arid Environments 90: 103-113.

Esler KJ, Holmes PM, Richardson DM, Witkowski ETF. 2008. Riparian vegetation management in landscapes invaded by alien plants: insights from South Africa. South African Journal of Botany 74: 397-400.

Esler KJ, Milton SJ, Dean WR. 2006. Karoo veld ecology and management. Pretoria: Briza Publications.

Fehmi JS. 2010. Confusion among three common plant cover definitions may result in data unsuited for comparison. Journal of Vegetation Science 21: 273-279.

Frias-Hernandez JT, Aguilar-Ledezma AL, Olalde-Portugal V, Balderas-Lopez JA, Gutierrez-Juarez G, Alvarado-Gil JJ, Castro JJ, Vargas H, Albores A, Dendooven L, Balderas-Lopez JA, Miranda LCM. 1999. Soil characteristics in semiarid highlands of central Mexico as affected by mesquite trees (Prosopis laevigata). Arid Soil Research and Rehabilitation 13: 305-312.

Gadzia JS, Ludwig JA. 1983. Mesquite age and size in relation to dunes and artifacts. Southwest Naturalist 28: 89-94.

Geesing D, Felker P, Bingham RL. 2000 Influences of mesquite (Prosopis glandulosa) on soil nitrogen and carbon development: implications for global carbon sequestration Journal of Arid Environments 46: 157-180.

Gibbens RP, Herbel CH, Morton HL, Lindeman WC, Ryderwhite JA, Richman DB, Huddleston EW, Conley WH, Davis CA, Reitzel $\mathrm{JA}$ et al. 1986. Some impacts of 2,4,5-T on a mesquite duneland ecosystem in southern New Mexico: a synthesis. Journal of Range Management 39: 320-326.

Hammer $\varnothing$, Harper DAT, Ryan PD. 2001. PAST: Paleontological Statistics Software Package for Education and Data Analysis. Available at http://palaeo-electronica.org/2001/past/issue101.htm [accessed 24 August 2010].

Herrick JE, van Zee JW, Havstad KM, Burkett LM, Whitford WG. 2005. Monitoring manual for grassland, shrubland and savanna ecosystems, vol. 1: Quickstart. Las Cruces: USDA-ARS Jornada Experimental Range.

Hoffman MT. 2000. Agricultural and ecological perspectives of vegetation dynamics and desertification. In: Arnalds $\mathrm{O}$, Archer S (eds), Rangeland desertification. Dordrecht: Kluwer. pp 507-534. Holmes PM, Esler KJ, Richardson DM, Witkowski ETF. 2008.
Guidelines for improved management of riparian zones invaded by alien plants in South Africa. South African Journal of Botany 74: 538-552.

Hope RA. 2006. Water, workfare and poverty: the impact of the Working for Water programme on rural poverty reduction. Environment Development and Sustainability 8: 139-156.

Iponga DM, Milton SJ, Richardson DM. 2009. Performance of seedlings of the invasive alien tree Schinus molle L. under indigenous and alien host trees in semi-arid savanna. African Journal of Ecology 48: 155-158.

Jacoby PW, Meadows CH, Foster MA. 1982. Honey mesquite control and forage response in Crane County, Texas. Journal of Range Management 35: 424-426.

Kincaid DR, Holt GA, Dalton PD, Tixier JS. 1959. The spread of Lehmann love-grass as affected by mesquite and native perennial grasses. Ecology 40: 738-742.

Klemmedson JO, Tiedemann AR. 1986. Long-term effects of mesquite removal on soil characteristics: II. Nutrient availability. Soil Science Society of America Journal 50: 476-480.

Klink CA, Joly CA. 1989. Identification and distribution of $C_{3}$ and $C_{4}$ grasses in open and shaded habitats in São Paulo State, Brazil. Biotropica 21: 30-34.

Kruskal J. 1964. Non-metric multidimensional scaling: a numerical method. Psychometrika 29: 115-129.

Le Maitre DC, van Wilgen BW, Gelderblom CM, Bailey C, Chapman RA, Nel JA. 2002. Invasive alien trees and water resources in South Africa: case studies of the costs and benefits of management. Forest Ecology and Management 160: 143-159.

Le Maitre DC, Versfeld DB, Chapman RA. 2000. The impact of invading alien plants on surface water resources in South Africa: a preliminary assessment. Water SA 26: 397-408.

Le Roux PM, Nel GP, Glen HF. 1994. Grazing plants of the Karoo and Karoo-like areas. Pretoria: Department of Agriculture.

MacDonald JH. 2009. Handbook of biological statistics. Baltimore: Sparky House Publishing.

Magurran AE. 2004. Measuring biological diversity. Oxford: Blackwell Publishing.

Manly BFJ. 1997. Randomisation, bootstrap and Monte Carlo methods in biology. London: Chapman and Hall.

Martin CS, Morton HL. 1993. Mesquite control increases grass density and reduces soil loss in southern Arizona. Journal of Range Management 46: 170-175.

Mazibuko DM. 2012. Phylogenetic relationships of Prosopis in South Africa: An assessment of the extent of hybridization, and the role of genome size and seed size in the invasion dynamics. MSc thesis, Stellenbosch University, South Africa.

McClaran MP, Angell DL. 2006. Long-term vegetation response to mesquite removal in desert grassland. Journal of Arid Environments 66: 686-697.

McCune B, Grace JB, Urban DL. 2002. Analysis of ecological communities. Gleneden Beach: MjM Software Design.

Meredith D. 1955. The grasses and pastures of South Africa. Parow: Central News Agency.

Meyer RE, Bovey RW. 1986. Influence of environment and stage of growth on honey mesquite (Prosopis glandulosa) response to herbicides. Weed Science 34: 287-299.

Milton SJ. 1995. Spatial and temporal patterns in the emergence and survival of seedlings in arid Karoo shrubland. Journal of Applied Ecology 32: 145-156.

Milton SJ, Dean WRJ. 1995. How useful is the keystone species concept, and can it be applied to Acacia erioloba in the Kalahari desert? Zeitschrift für Ökologie und Naturschutz 4: 147-156.

Milton SJ, Dean WRJ. 1998. Alien plant assemblages near roads in arid and semi-arid South Africa. Diversity and Distributions 4: 175-187.

Milton SJ, Dean WRJ, Richardson DM. 2003. Economic incentives for restoring natural capital in Southern African rangelands. Frontiers in Ecology and the Environment 1: 247-254. 
Milton SJ, Wilson JRU, Richardson DM, Seymour CL, Dean WRJ, Iponga DM, Proche A. 2007. Invasive alien plants infiltrate bird-mediated shrub nucleation processes in arid savanna. Journal of Ecology 95: 648-661.

Ndhlovu T. 2011. Impact of Prosopis (mesquite) invasion and clearing on ecosystem structure, function and agricultural productivity in semi-arid Nama Karoo rangeland, South Africa. MSc thesis, Stellenbosch University, South Africa.

Ndhlovu T, Milton-Dean SJ, Esler KJ. 2011. Impact of Prosopis (mesquite) invasion and clearing on the grazing capacity of semiarid Nama Karoo rangeland, South Africa. African Journal of Range and Forage Science 28: 129-137.

Ndhlovu T, Milton SJ, Esler KJ. 2016. Effect of Prosopis (mesquite) invasion and clearing on vegetation cover in semi-arid Nama Karoo rangeland, South Africa. African Journal of Range and Forage Science 33: 11-19.

Oksanen J, Blanchet FG, Kindt R, Legendre P, Minchin PR, O'Hara RB, Simpson GL, Solymos P, Stevens MHH, Wagner H 2015. vegan: Community Ecology package. $R$ package version 2.2-1. Available at http://CRAN.R-project.org/package=vegan [accessed 9 April 2015].

Palmer AR, Hoffman MT. 1997. Nama karoo. In: Cowling RM, Richardson DM, Pierce SM (eds), Vegetation of southern Africa. Cambridge: Cambridge University Press. pp 167-186.

Pease S, Ffolliott PF, Gottfried GJ, DeBano LF. 2006. Mesquite removal and mulching impacts on herbage production on a semi desert grass-shrub rangeland. Fort Collins: US Department of Agriculture, Forest Service.

R Core Team. 2014. R: a language and environment for statistical computing. Vienna. R Foundation for Statistical Computing.

Reyes-Reyes G, Baron-Ocampo L, Cuali-Alvarez I, FriazHernandez JT, Fregoso LV, Dendooven L. 2002. C and N dynamics in soil from the central highlands of Mexico as affected by mesquite (Prosopis spp) and huizache (Acacia tartuoso): a laboratory investigation. Applied Soil Ecology 19: 27-34.

Richardson DM, Bond WJ, Dean WRJ, Higgins SI, Midgley GF, Milton SJ, Powrie LW, Rutherford MC, Samways MJ, Schulze RE. 2000. Invasive alien species and global change. In: Mooney HA, Hobbs RJ (eds), Invasive aliens in a changing world. Washington DC: Island Press. pp 303-349.

Richardson DM, van Wilgen BW. 2004. Invasive alien plants in South Africa; how well do we understand the ecological impacts? South African Journal of Science 100: 45-52.

Rutherford MC, Powrie LW, Husted LB. 2014. Herbivore-driven land degradation: consequences for plant diversity and soil in arid subtropical thicket in south-eastern Africa. Land Degradation and Development 25: 541-553.

Ruthven DC. 2001. Herbaceous vegetation diversity and abundance beneath honey mesquite (Prosopis glandulosa) in the South Texas plains. Texas Journal of Science 53: 171-186.

Saayman N, Botha JC. 2007. Vegetation changes as a result of control of Prosopis in the Nama-Karoo. Abstracts of the Arid Zone Ecology Forum, Sutherland. Available at www.azef.co.zal meetings/2007/prog2007.pdf [accessed 9 January 2014].

Schachtschneider K, February EC. 2013. Impact of Prosopis invasion on a keystone tree species in the Kalahari Desert. Plant Ecology 214: 597-605.

Scifres CJ, Kothmann MM, Mathis GW. 1974. Range site and grazing system influence regrowth after spraying honey mesquite. Journal of Range Management 27: 97-100.

Scifres CJ, Polk DB. 1974. Vegetation response following spraying a light infestation of honey mesquite. Journal of Range Management 27: 462-465.

Shackleton RT, Le Maitre DC, Richardson DM. 2015a. Prosopis invasions in South Africa: population structures and impacts on native tree population stability. Journal of Arid Environments 114: $70-78$.

Shackleton RT, Richardson DM, Le Maitre DC, van Wilgen BW. 2015b. The impact of invasive alien Prosopis species (mesquite) on native plants in different environments in South Africa. South African Journal of Botany 97: 25-31.

Shapiro SS, Wilk MB. 1965. An analysis of variance test for normality (complete samples). Biometrika 52: 591-611.

Shearing D, van Heerden K. 1994. Karoo: South African wild flower guide 6. Kirstenbosch: Botanical Society of South Africa.

Simmons MT, Archer SR, Teague WR, Ansley RJ. 2008. Tree (Prosopis glandulosa) effects on grass growth: an experimental assessment of above-and-belowground interactions in a temperate savanna. Journal of Arid Environments 72: 314-325.

Steenkamp HE, Chown SL. 1996. Influence of dense stands of an exotic tree Prosopis glandulosa Benson, on a savanna dung beetle (Coleoptera: Scarabeidae) assemblage in southern Africa. Biological Conservation 78: 305-311.

Suttie JM, Reynolds SG, Batello C. 2005. Grasslands of the world. Rome: Food and Agricultural Organization of the United Nations.

Tiedemann AR, Klemmedson JO. 1973. Effect of mesquite on physical and chemical properties of the soil. Journal of Range Management 26: 27-29.

Tiedemann AR, Klemmedson JO. 1977. Effect of mesquite trees on vegetation and soils in the desert grassland. Journal of Range Management 30: 361-367.

Tiedemann AR, Klemmedson JO. 2004. Responses of desert grassland vegetation to mesquite removal and regrowth. Rangeland Ecology and Management 57: 455-465.

van Wilgen BW, Forsyth GG, Le Maitre DC, Wannenburg A, Kotzé JDF, van den Berg E, Henderson L. 2012. An assessment of the effectiveness of a large, national-scale invasive alien plant control strategy in South Africa. Biological Conservation 148: 28-38.

van Wilgen BW, Le Maitre DC, Cowling RM. 1998. Ecosystem services, efficiency, sustainability and equity: South Africa's Working for Water programme. Trends in Ecology and Evolution 13: $378-378$.

van Wilgen BW, Reyers B, Le Maitre DC, Richardson DM, Schonegevel L. 2008. A biome-scale assessment of the impact of invasive alien plants on ecosystem services in South Africa. Journal of Environmental Management 89: 336-349.

van Wilgen BW, Richardson DM, Le Maitre DC, Marais C, Magadlela D. 2001. The economic consequences of alien plant invasions: examples of impacts and approaches to sustainable management in South Africa. Environment, Development and Sustainability 3: 145-168.

Varshney CK. 1968. Autecology of Aristida adscensionis Linn. Proceedings of the Indian National Science Academy 38B: 13-35.

Veenendaal EM, Shushu DD, Scurlock JMO. 1993. Responses to shading of seedlings of savanna grasses with different $\mathrm{C}_{4}$ photosynthetic pathways. Journal of Tropical Ecology 9: 213-229.

Yurkov AM, Kemler M, Begerow D. 2011. Species accumulation curves and incidence-based species richness estimators to appraise the diversity of cultivable yeasts from Beech forest soils. PLoS ONE 6: e23671.

Zimmermann HG. 1991. Biological control of mesquite, Prosopis spp. (Fabaceae), in South Africa. Agriculture, Ecosystems and Environment 37: 175-186.

Zimmermann HG, Pasiecznik NM. 2005. Realistic approaches to the management of Prosopis in South Africa. Available at: http:// www.research4development.infor/PDF/outputs/Forestry/R7295_ South Africa_Prosopis brief.pdf [accessed 9 January 2014]. 